\title{
Management model and feasibility of agroforestry practices in Sipolha Horison village, Simalungun regency, North Sumatra province, Indonesia
}

\author{
Agus Purwoko ${ }^{1, *}$, Alfan Gunawan Ahmad ${ }^{1}$, and Jawanri Maurisco Saragih ${ }^{1}$ \\ ${ }^{1}$ Department of Forest Management, Faculty of Forestry, Universitas Sumatera Utara. J1. Tridarma \\ Ujung No. 1, Medan 20155, North Sumatra, Indonesia
}

\begin{abstract}
Agroforestry is a deliberate combination of agriculture and forestry to create an integrated environment and sustainable land use system. This study aims to identify the form of agroforestry management and the financial feasibility of agroforestry in Sipolha Horison Village. The research method is descriptive analysis and financial analysis using NVP, $\mathrm{BCR}$, and IRR parameters. The results showed that there were two agroforestry patterns commonly practiced by the people of Sipolha Horison Village, Pematang Sidamanik District, namely agroforestry pattern A (suren and coffee plants) and agroforestry pattern B (suren, coffee, and clove plants). The results of the analysis show that suren agroforestry produces an NPV value of Rp. 166,343,919, - per ha (at an interest rate of $8 \%$ ), Rp. 126,566,124, 51 per ha (at an interest rate of $10 \%$ ), and Rp. 73,322,098.68 per ha (at an interest rate of 14\%). The BCR value with an interest rate of $8 \%$ is 4.29 , at a $10 \%$ interest rate is 3.78 , and at a $14 \%$ interest rate is 2.94 , with an IRR value of $17.6 \%$. Overall these results indicate that agroforestry practices in Sipolha Horison Village, Pematang Sidamanik District, Simalungun Regency are feasible to cultivate.
\end{abstract}

\section{Introduction}

The practice of agroforestry (agroforestry) has started since humans switched traditions from hunting to farming in $7000 \mathrm{BC}$. One of the goals in the Medium Term Development Plan (RPJM) is in the form of community welfare by applying the principles of sustainability and resilience to forest resources, so agroforestry is an option [1]. Agroforestry is a land use system that combines trees and plants or animals simultaneously or sequentially to increase the overall production of crops and livestock on a common land under technology conditions and management actions that are in accordance with the sustainable culture of local communities [2-5].

Agroforestry systems have been implemented by several regions in Indonesia. The application of agroforestry systems is useful as a source of livelihood and climate change

* Corresponding author: agus9@usu.ac.id 
control [6]. Ecologically the agroforestry system is better to implement than the monoculture system because it is more resistant to pests and diseases and the resulting productivity is also greater. The agroforestry system can also guarantee food security because of the continuity of stable production, because it supports if one plant does not produce then there are other crops that can be harvested [7,8]. Related to aspects of ecosystem sustainability, welfare and economic prosperity, food security and community resilience in the face of economic crises, it is suspected that the choice of farming by applying the agroforestry pattern is the right solution [9-11].

Suren is a type of forestry plant that has many benefits. The suren tree is a large tree with a straight trunk that can reach a height of $40-60 \mathrm{~m}$ with a branch-free height of $25 \mathrm{~m}$ and a diameter of $100 \mathrm{~cm}$. $[12,13]$.Suren is one of the forestry commodities that produces wood that has high economic value and has good wood properties. Suren wood belongs to the medium class, namely IV-V. The need for this type of wood is increasing, due to the decreasing type of wood that comes from natural forests. Ensuring the fulfillment of the needs of the woodworking industry requires types of plants that grow fast and have high selling power. One of them is suren (Toona sureni Merr). Suren is a fast-growing wood that can live on land that has a low $\mathrm{pH}$, has the potential to be used as a type of rehabilitation plant for degraded land, has many uses and has high selling power [14,15].

The community is part of the environmental ecosystem that directly or indirectly interacts and affects the benefits derived from the conservation and enhancement program of resources, the interactions carried out by the community in plant management can have an impact on improving socio-economic conditions. The people of Sipolha Horison Village, Pematang Sidamanik Subdistrict, mostly make a living as farmers. Suren is a forestry plant that is used by the community as an agroforestry plant that has economic value so that it can have an effect on increasing the economic income of the community.

This study aims to identify the form of agroforestry management and the financial feasibility of agroforestry in Sipolha Horison Village, Pematang Sidamanik District, Simalungun Regency, North Sumatra Province, Indonesia.

\section{Materials and methods}

This research was conducted in Sipolha Horison Village, Pematang Sidamanik District, Simalungun Regency, North Sumatra Province, Indonesia.

The research data taken are primary data and secondary data. Primary data collected include data obtained from community respondents, the form of processing suren (Toona sureni), Coffee and Cloves. The sampling method in this research is descriptive which is a method of taking respondents intentionally based on the research objectives.

\subsection{Analysis of agroforestry management forms}

Obtaining results or information on the analysis of forms of agroforestry management can be obtained from resource persons and field data by means of interviews and field observations.

\subsection{Financial feasibility analysis}

Financial analysis is carried out to determine the benefits obtained, the costs incurred, the benefits, when the investment returns occur and the interest rate on investments that provide benefits.

a. Net Present Value (NPV) 
Net Present Value, the current value of an agroforestry activity or business, is calculated by the following formula:

$$
\mathrm{NPV}=\sum_{t=1}^{n} \frac{B t-C t}{(1+i)^{2}}
$$

Where:

$$
\begin{array}{ll}
\mathrm{NPV} & =\text { Current net value } \\
\mathrm{Bt} & =\text { Patent benefit in year } \mathrm{t} \\
\mathrm{Ct} & =\text { Cost } / \text { cost in year } \mathrm{t} \\
\mathrm{i} & =\text { Interest rate } \\
\mathrm{t} & =\text { Time period }
\end{array}
$$

The indicators for determining eligibility in the Net Present Value can be classified as follows:

$\mathrm{NPV}=0$ then the value of the agroforestry business is equal to the interest rate prevailing at the bank

NPV $>0$ then agroforestry business is profitable

$\mathrm{NPV}<0$ then agroforestry business loses

b. Benefit Cost Ratio (BCR)

Comparison of benefits to costs of an agroforestry activity or business, calculated by the following formula:

$$
\mathrm{BCR}=\frac{\text { Present value of benefit }}{\text { Present value of costs }}=\frac{(\mathrm{PV}) \mathrm{B}}{(\mathrm{PV}) \mathrm{C}}
$$

Where:

$(\mathrm{PV}) \mathrm{B}=$ present value of benefit $(\mathrm{Rp})$

$(\mathrm{PV}) \mathrm{C}=$ present value of costs $(\mathrm{Rp})$

The indicators for determining eligibility in the Benefit Cost Ratio can be classified as follows:

$\mathrm{BCR}>1$ then the agroforestry business is profitable

$\mathrm{BCR}<1$ then the agroforestry business loses

$\mathrm{BCR}=1$ neutral

c. Internal Rate of Return (IRR)

It is a parameter at the interest rate at which agroforestry businesses make a profit, calculated by the following formula.

$$
\sum_{t=0}^{n} \frac{(C) t}{(1+i)^{t}}=\sum_{t=0}^{n} \frac{(C o) t}{(1+i)^{t}}
$$

Where:

IRR = Profit rate

(C) $\mathrm{t} \quad=$ Cash flow in year $\mathrm{t}(\mathrm{Rp})$

(Co)t $=$ Cash outflow in year $\mathrm{t}(\mathrm{Rp})$

I $\quad=$ Interest rate (in decimal)

$\mathrm{n} \quad=$ age of business

$\mathrm{t}=$ time

The indicators for determining eligibility in the Internal Rate of Return can be classified as follows:

IRR $i$ then agroforestry business is feasible

IRR $<\mathrm{i}$ then agroforestry business is not feasible 


\section{Results}

\subsection{Management of the suren agroforestry system in sipolha horison village}

\subsubsection{Agroforestry patterns}

Based on the results of field observations and direct interviews with farmers, it was found that various types of plants were cultivated. Overall, suren agroforestry cultivation patterns in the research location are grouped into two, namely:

a. Pattern A (Combination of Suren and Coffee plants)

Coffee is a suren agroforestry combination that is often done by farmers in Sipolha Horison village. The suren plant, which is planted as an intercrop, is planted by the community as a protective plant for coffee. Apart from being a protective plant for coffee, this cropping pattern is also considered as a coffee hedge by respondent farmers that can help in repelling pests that can damage coffee plants. This is because suren has a cedar-like scent that insects don't like. This cropping pattern also has a sufficient number of suren crops to be harvested later by farmers (for farmers who plant on their own land).

In the area around Sipolha Village, suren plants are also used by farmers as trees to mark land boundaries. Suren plants planted as land boundaries by farmers serve as markers of community land boundaries or as boundaries for community farming land.

b. Pattern B (Combination of Suren, Coffee and Clove plants)

In suren agroforestry with coffee, farmers in Sipolha Village also combine cloves to fulfill their economic resources. The process of harvesting cloves belongs to the easy category, that's why farmers combine cloves in the middle of a blend of coffee and suren. The steps for harvesting cloves are picking, sorting, and drying.

\subsubsection{Seeding and planting}

In providing seeds, the community in Sipolha Horison village has ways to produce seeds, namely:

1. Seeds from under the tree

The seeds to be planted are taken directly from under the suren or coffee trees whose height has not yet reached $10 \mathrm{~cm}$, this is intended so that when retraction does not damage the roots. In addition, if the process of taking the seeds is not good, it can cause the seeds to rot and growth to be slow and die. Seeds taken can be moved first into polybags or directly planted in the planting place. Planting is done with the spacing of each type of plant. Suren plants have a spacing of $5 \times 5 \mathrm{~m}$, coffee plants have a spacing of $2 \times 2 \mathrm{~m}$, while cloves have a spacing of $10 \times 10 \mathrm{~m}$.

\section{Nursery}

For the nursery, there is no special treatment. The ripe seeds are sorted by winnowing first, to remove the seeds that are not good / hollow. After that, it is spread in the nursery that has been loosened first and mixed with compost. After it grows to a height of $5 \mathrm{~cm}$, it is transferred to a polybag which has been filled with topsoil and compost soil with a composition of 60:40 waiting for the size to be $10-20 \mathrm{~cm}$ and planted to the planting location.

\subsubsection{Maintenance}

The maintenance carried out is just monitoring so that the suren tree is not exposed to fire or sharp objects, both machetes and hoes which can cause rotting of the stems. The 
community only makes modest pruning on branches if the branches have covered agricultural crops, both coffee and other plants that have the potential to interfere with growth. Fertilization is carried out on coffee plants according to the time period set by the farmer, from this fertilization other plants produce the substances needed by the plant.

\subsubsection{Harvesting}

For tree harvesters, the community hires tree cutting services using a wood saw machine. Also in its formation for the use of tree trunks as house materials in the form of boards and broti. Although the results of the formation are less efficient, the relatively low cost is the main reason for its use.

The thing that the local community pays the most attention to is when the trees fall leaves or at the time of leaf change. Based on information obtained from the community, this is intended so that the stems do not bend after harvesting and shaping either into boards, brocade or ship material.

\subsection{Cost analysis}

Every farming business carried out by someone needs to know the feasibility and benefits that can be obtained from the business so that it can be used for policy makers or users of other investment information instruments. The assessment of the financial feasibility of suren and arabica coffee agroforestry begins with a cost analysis. This cost analysis is in the form of all costs incurred by farmers in their efforts to produce suren wood and arabica coffee beans. All of these costs are calculated and grouped into fixed investment costs (fixed costs), direct investment costs (variable costs), and operational costs (operational costs).

\subsubsection{Fixed investment cost}

One type of cost that needs to be analyzed is fixed cost. Fixed investment costs are a type of cost that in a certain capacity the amount does not change even though the amount of production changes.

The fixed investment costs for suren agroforestry at the research site consist of the costs of procuring agricultural equipment such as hoes, machetes, beko, hand sprayer, gembor, and pulper. Agricultural equipment used by farmers has a service life. Agricultural equipment such as machetes, hoes, beko, hand sprayers have a service life of 5 years. Meanwhile, farming equipment such as buckets have a service life of 3 years and pulpers 10 years.

Table 1. Fixed investment needs for suren agroforestry management.

\begin{tabular}{|l|l|c|c|r|r|}
\hline No & Tool type & $\begin{array}{l}\text { Economic Life } \\
\text { Years }\end{array}$ & Number of units & Price/unit (Rp) & Price (Rp) \\
\hline 1 & Hoe & 5 & 2 & 70,000 & 140,000 \\
\hline 2 & machete & 3 & 2 & 50,000 & 100,000 \\
\hline 3 & Beko & 5 & 1 & 300,000 & 300,000 \\
\hline 4 & $\begin{array}{l}\text { Medicine } \\
\text { sprayer }\end{array}$ & 10 & 1 & 500,000 & 500,000 \\
\hline 5 & cheers & 2 & 2 & 50,000 & 100,000 \\
\hline 6 & Bucket & 3 & 5 & 10,000 & 50,000 \\
\hline 7 & Pulper & 10 & 1 & 300,000 & 300,000 \\
\hline 8 & Bag & 2 & 10 & 5,000 & 50,000 \\
\hline & Amount & & & & $1,540,000$ \\
\hline
\end{tabular}


Table 1 above shows the types of agricultural equipment needed, the number per unit that has been averaged from all respondents needed and the costs needed to manage suren agroforestry. Based on the table, it shows that the total average fixed investment cost for suren agroforestry management is Rp. 1,540,000. details of the need for fixed investment during the crop cycle for each respondent farmer during the crop cycle (15 years) and the amount of each unit converted into needs per hectare.

\subsubsection{Direct investment cost}

Direct investment costs (variable costs) are costs whose amount is affected by changes in the amount of output produced. The cost of direct investment will increase if the amount of output produced increases and will decrease if the output produced decreases. These types of costs include the costs of procuring seeds, fertilizers, various types of drugs (pesticides and herbicides), and labor (land preparation, planting, maintenance, and harvesting. Details of the need for direct investment during the crop cycle for each respondent farmer during plant cycle.

The community needs agricultural equipment purchased at the sub-district market of each location. The types of tools needed by the community in the management of suren agroforestry are:

Procurement of seeds needed are coffee seeds and suren seeds. In the research location, most of the arabica coffee seeds obtained by the community came from the farmer's own nurseries and the others came from local nurseries.

Fertilizers that are generally used by farmers at the research site are in the form of manure, Urea, and NPK. Manure is used when land preparation is carried out, namely before planting. Then for Urea and NPK fertilizers are given by the community when the planting is complete. The community provides Urea and NPK fertilizers twice a year.

In their maintenance activities, farmers also use drugs. The types of drugs used by farmers are in the form of pesticides and herbicides. Herbicides are used to kill weeds and pesticides to kill pests on coffee plants.

In the research location, the community in general does not use herbicides much in coffee cultivation activities. In general, labor used is labor within the family and labor outside the family (wages). Family workers in the form of female and male workers, both adults and children with different working time capacities, while wage workers are adult female or male workers.

Table 2. Direct investment cost of suren agroforestry management.

\begin{tabular}{|c|c|c|c|c|c|}
\hline No & Type of Financing & Unit & Amount & Price $(\mathrm{Rp})$ & Price $(\mathrm{Rp})$ \\
\hline 1 & $\begin{array}{ll}\text { Seeds } & \\
\text { a. } & \text { Suren } \\
\text { b. } & \text { Coffee } \\
\text { c. } & \text { Clove }\end{array}$ & $\begin{array}{l}\text { stem } \\
\text { stem } \\
\text { stem }\end{array}$ & $\begin{array}{r}400 \\
2,500 \\
100\end{array}$ & $\begin{array}{r}3,000 \\
2,000 \\
20,000\end{array}$ & $\begin{array}{l}1,200,000 \\
5,000,000 \\
2,000,000\end{array}$ \\
\hline 2 & $\begin{array}{l}\text { Maintenance/ } \\
\text { Fertilization }\end{array}$ & & & & $2,000,000$ \\
\hline 3 & $\begin{array}{l}\text { Land preparation } \\
\text { suren planting } \\
\text { Coffee planting } \\
\text { Clove planting } \\
\text { Weed spray }\end{array}$ & $\begin{array}{l}\text { HOK } \\
\text { HOK } \\
\text { HOK } \\
\text { HOK } \\
\text { HOK }\end{array}$ & $\begin{array}{r}10 \\
5 \\
10 \\
5 \\
5\end{array}$ & $\begin{array}{l}100,000 \\
100,000 \\
100,000 \\
100,000 \\
100,000\end{array}$ & $\begin{array}{r}1,000,000 \\
500,000 \\
1,000,000 \\
500,000 \\
500,000 \\
\end{array}$ \\
\hline & Amount & & & & 13.700 .000 \\
\hline
\end{tabular}


In Table 2, it displays the types of financing from direct investment, the amount of each type of financing, and fixed investment costs paid by farmers. The direct investment cost incurred by farmers during the cycle is $\mathrm{Rp} .13,700,000$ per ha.

\subsubsection{Operational cost}

Operational costs are a number of costs that must be incurred to support the business activities carried out. The operational costs or routine costs of this agroforestry business are incurred by farmers in a certain period of time during the farming cycle. In suren agroforestry management issued by farmers in the form of land rent every year. The cost of land rent incurred by farmers in this suren agroforestry management is IDR 700,000/year.

This fee is a fee that must or is required for farmers to carry out sustainable land management. In the suren agroforestry management process, land rent is paid for during the agroforestry harvest rotation cycle, which is 15 years. Labor is human labor which is expressed in daily units of working people (HOK) with units of 8 hours per day.

Table 3. Operational cost of suren agroforestry management.

\begin{tabular}{|l|l|l|l|}
\hline No & Type of Financing & Cost $(\mathrm{Rp})$ & Cost $(\mathrm{Rp})$ \\
\hline 1 & Land lease & 700,000 & 700,000 \\
\hline & Amount & & 700,000 \\
\hline
\end{tabular}

Based on Table 3, it is found that the land rental fee that must be paid regularly by farmers is $\mathrm{Rp}$. 700,000/year to manage suren agroforestry, thus farmers must pay the land rent according to the rotation cycle of suren agroforestry, which is for 15 years or Rp. $700,000 \times 15=$ IDR $10,500,000$. The total expenditure on rent for suren agroforestry land that must be paid by farmers during the rotation cycle of suren agroforestry is Rp. $10,500,000 /$ rotation cycle.

\subsection{Financial feasibility of agroforestry business}

Financial feasibility criteria are related to success, the financial feasibility of agroforestry business which is intended in this study is how much income has been received which has been discounted from the application of the agroforestry pattern.

\subsubsection{NPV (net present value)}

The assumption used in this financial analysis of suren agroforestry has increased in the 7th year, this is due to the age of coffee in that year being a productive age and also the beginning of the clove harvest so that it has increased. This is in accordance with the results of the study that the production pattern of suren agroforestry business according to plant age in general is as follows: (a) stage I, production has occurred which occurred in year 3, namely by harvesting coffee plants, (b) stage II, production increased which occurred in the 7 th year, namely the productive age of coffee plants and the start of harvesting of cloves, (c) stage III, production was reduced in the 11th year because the productive age of coffee had passed and in the 15 th year suren was harvested.

The NPV criterion is based on the concept of discounting all cash flows to their present value. The interest rates used are $8 \%, 10 \%$, and $14 \%$. From the results of the analysis, it is known that the NPV value is positive, meaning that the agroforestry pattern is financially feasible. The higher the NPV value, the better the business, as stated in the indicator for 
determining eligibility in the net present value (NPV), namely if NPV $>0$ then the agroforestry business is profitable.

Based on Table 4, the NPV values obtained during a 15-year rotation cycle with interest rates of $8 \%, 10 \%$, and $14 \%$ are as follows: At an interest rate of $8 \%$, the NPV value is $166,343,919.74$ per ha, at an interest rate of $10 \%$ the NPV value is $126,566,124.51$ per ha, while with an interest rate of $14 \%$ obtained an NPV value of 73,322,098.68 per ha.

From the data on the agroforestry business, a positive NPV value or more than zero is obtained, as an indicator for determining eligibility which is shown if NPV $>0$ then the agroforestry business is profitable, this indicates that the net benefits received from suren agroforestry business in Sipolha Horison Village, Pematang Sidamanik District, Simalungun Regency is feasible.

Table 4. Suren agroforestry financial analysis.

\begin{tabular}{|c|c|c|c|c|c|c|}
\hline NPV 8\%/ha & NPV 10\%/ha & NPV 14 /Ha & $\begin{array}{c}\text { BC } \\
8 \%\end{array}$ & $\begin{array}{c}10 \% \\
\text { BCR }\end{array}$ & $\begin{array}{c}\text { BCR } \\
14 \%\end{array}$ & IRR (\%) \\
\hline $66,343,919.74$ & $26,566,124.51$ & $73,322,098.68$ & 4.29 & 3.78 & 2.94 & 17.6 \\
\hline
\end{tabular}

\subsubsection{BCR (benefit cost ratio)}

From the results of the analysis carried out, the BCR value for suren agroforestry business with each interest rate is $8 \%$ with a value of $4.29 \%$, an interest rate of $10 \%$ with a value of $3.78 \%$, and at an interest rate of $14 \%$ with a value of $2.94 \%$, this shows that every present value, every expenditure of Rp. 1 will add to the net income value of each interest rate. For an $8 \%$ interest rate, it was Rp.4.29, a 10\% interest rate was Rp.3.78, and for a $14 \%$ interest rate it was Rp.2.94.

From the results of the calculation of the BCR value of suren agroforestry businesses with interest rates of $8 \%, 10 \%$, and $14 \%$, it shows that the BCR value is more than one, as an indicator of determining eligibility in the Benefit Cost Ratio (BCR) if BCR $>1$ then the agroforestry business is profitable., This shows that the net benefits received from the suren agroforestry business in Sipolha Horison Village, Pematang Sidamanik District, Simalungun Regency are feasible.

\subsubsection{Internal rate of returns (IRR)}

Internal Rate Returnis the interest rate that equates the present value of the expected cash outflows with the present value of the expected cash inflows, or is also defined as the interest rate that causes the Net Present Value (NPV) to be zero. Shows the maximum interest rate that can be paid by a business or in other words is the ability to earn income from the money invested [16].

From the results of data analysis, the results of the calculation of the internal rate of return from the suren agroforestry business implemented by farmers in Sipolha Horison Village, Pematang Sidamanik District, Simalungun Regency obtained the results of the internal return flow of $17.6 \%$, as the parameter used is if the IRR $i$ then the agroforestry business is feasible, thus the results of the Internal Rate of Return analysis are $17.6 \%$ greater than the interest rate used.

\section{Discussion}


With the agroforestry pattern, several types of plants can be produced separately depending on the type of plant. This is because the types of plants found in agroforestry land vary and the harvest period is different for each plant. Some are harvested every day like cloves when it's harvest season and every week like coffee. Thus, there are variations in harvesting between each type of product in obtaining agroforestry income. This is in accordance with the statement [17] which states that the mixed garden cropping pattern provides varied income which is routine, daily, weekly, monthly, seasonal, and yearly so that mixed gardens or what we call agroforestry can provide sustainable results for farmers. .

The main purpose of the community to combine suren plants with other crops is to increase the income of farmers, so that farmers have income other than expecting production from suren wood. The income referred to in this study is the income or income obtained by farmers from the results of each type of plant cultivated. Basically, farmers are producers who not only aim to get high production yields, but also aim to obtain high incomes as well, this is in accordance with that agroforestry management is related to optimizing land use to meet the needs of farmers [18].

Suren trees can be harvested with $>15$ years and not all suren trees that are 15 years old can be harvested, because the diameters of the trees are different. Meanwhile, some farmers use suren trees only as intercrops, windbreaks, road shading, and land boundaries. According to Hana (2016) stated that suren trees that can be sold are suren trees that have a diameter of $30 \mathrm{~cm}$. Suren stands with a diameter of $30 \mathrm{~cm}$ are valued at IDR 1,000,000 IDR 2,000,000, the average market price for suren stands is IDR 1,000,000 during the research.

From the results of the analysis of suren agroforestry businesses in Sipolha Horison Village, Pematang Sidamanik District, Simalungun Regency, this is feasible because the NPV value obtained is positive or more than zero, the BCR value from the agroforestry business is more than one, and the IRR value obtained is higher. of the interest rate value and the three conditions meet the indicators for determining eligibility in the financial feasibility analysis. The results obtained are not much different from the results of previous studies, such as:

The results of research [19] which show the calculation of the financial feasibility analysis of a suren agroforestry with coffee plants. In this study, suren agroforestry business was also declared feasible because the indicated indicators had been met. This research was conducted at an interest rate of $5.65 \%$. The calculation of the NPV value was Rp.166.792.215.73/daur/UT.

The results of research [20] which show the analysis of community income on suren agroforestry with cocoa plants. Based on the results of the financial feasibility parameters carried out in this study, namely the NPV BCR and IRR obtained, the agroforestry business using cocoa and suren crops in Mekar Sari Raya Village, Panei District is financially feasible to be cultivated and developed with income analysis carried out at the local level. an interest rate of $12 \%$ obtained a Net Present Value (NPV) of Rp.2,375,224,938.62 for 15 years, Gross B/C Ratio (BCR) 2.1\%, Internal Rate of Return (IRR) 28\% and Payback Period ( PP) for 5 years 4 months 12 days. Suren is one of the forestry commodities that produces wood of high economic value and has good wood properties. The suren tree can be used for wood and non-timber products. A lot of literature describes various techniques of utilizing parts of suren trees, in various regions in Indonesia [20].

From the comparison results with other studies, it is known that suren agroforestry cultivation is feasible, but has not run optimally because there is no careful planning from the beginning of the suren agroforestry business process so that it tends to produce an unsatisfactory end. However, if carried out with planned management, suren agroforestry business will greatly contribute to increasing farmers income. 


\section{Conclusion}

In the management of the agroforestry system, there are two commonly applied agroforestry patterns, namely Pattern A (a combination of suren and coffee plants) and pattern B (a combination of suren, coffee and clove plants). The main activities carried out include seeding, planting, maintenance, and harvesting. Based on the results of the financial analysis of suren agroforestry, it shows that the suren agroforestry pattern is feasible. The NPV value obtained at an interest rate of $8 \%$ of Rp. 166.343,919.74 per ha, at an interest rate of $10 \%$ of Rp. 126.566124 .51 per ha, and at an interest rate of $14 \%$ of $\mathrm{Rp}$. 73.322 .098 .68 per ha. The BCR value with an interest rate of $8 \%$ is 4.29 , at a $10 \%$ interest rate is 3.78 , and at a $14 \%$ interest rate is 2.94 , with an IRR value of $17.6 \%$.

Thank you to the community Sipolha Horison Village, Pematang Sidamanik District, Simalungun Regency, North Sumatra Province,and all parties who have helped facilitate the implementation of this research.

\section{References}

1. Santoso, I, Strategi Penelitian Wanatani (Agroforestry) di Indonesia (Kementerian Kehutanan, Jakarta, 2012)

2. Hairiah K and Rahayu S, Pengukuran 'karbon tersimpan' di berbagai macam penggunaan lahan Bogor [in Indonesian] (Indonesia: World Agroforestry Centre ICRAF, SEA Regional Office, University of Brawijaya, Unibraw, Indonesia, 2007)

3. Paembonan, S. A, Model Agroforestri Berbasis Tongkonan yang Berwawasan Konservasi Lingkungan di Kabupaten Tana Toraja in Kuswantoro et al. (eds) Agroforestry for Food and Better Environment-National Seminar of Agroforestry [in Indonesian with English summary] Proc. of National Seminar on Agroforestry (Malang, 2013)

4. Paembonan, S. A., S. Millang., M. Dassir., M. Ridwan, IOP Conf. Series: Earth and Environmental Science, 157, 012004 (2018)

5. Azhar, RisnasariI, Muhdi, Srena MF, Riswan, IOP Conf. Series Earth Environmental Sci, 305, 012016 (2019)

6. Mahendra, F, Sistem Agroforestri dan Aplikasinya (Graha Ilmu, Yogyakarta, 2009)

7. Rianse, U., Abdi, Agroforestri: Solusi Sosial dan Ekonomi Pengelolaan Sumber Daya Hutan (Alfabeta, Bandung, 2010)

8. Wicaksono, K.P., Suryanto, A., Nugroho, A., Nakagoshi, N., Kurniawan, N, Indonesia. Agrivita, 33, 75-84 (2011)

9. Baka, W. K., I. S. Rianse., U. Rianse., W. G. Abdullah., Zulfikar, IOP Conf. Series: Earth and Environmental Science, 314, 012041 (2019)

10. Umar, Y. P., Tomohiro, H., Satoshi I., Momoka, M., Takuro, M., Adi, S., Yasushi, M., Ryoko, H., Tsuyoshi, K., Hagus, T., Kurniawan, P. W., Arifin, N. S, Vegetation Science, 36, 61-70 (2019)

11. Nyamukuru, M. K. A., Daniel, M., John, R. S. T, International Journal of Forestry Research, 9, 2 (2017)

12. Latifah, S., A. Purwoko., K. S. Hartini., A. Sadeli., T. N. R Tambal, IOP Conf. Series: Earth and Environmental Science, 374, 012035 (2019)

13. Kholibrina, C, Menanam Ingul/Suren (Medan, 2009) 
14. Latifah, S., Yunus, A.,Sri, W, Earth and Environmental Science/ International Conference on Agriculture, Environment, and Food Security (2018)

15. Umaya, S, Analisis Kelayakan Usaha Budidaya Cacing Tanah (Lumbricus Rubellus)pada Magenta Farm di Desa Nanggung Bogor (Departemen Manajemen, Fakultas Ekonomi dan Manajemen, Insitut Pertanian Bogor, Bogor, 2010)

16. Widiarti, A., S. Prajadinata, Karakteristik Hutan Rakyat Pola Kebun Campuran, (Bogor, 2008)

17. Naibaho, I E, Latifah. S, dan Martial. T, Jenis Produk dan Pola Agroforestri di Desa Sosor Dolok, Kecamatan Harian, Kabupaten Samosir (Product types and patterns of agroforestry in Sosor Dolok Village, District Harian, Samosir Regency) (Program Studi Kehutanan, Fakultas Pertanian, Universitas Sumatera Utara, 2014)

18. Situmeang, H, Analisis Kelayakan Finansial Agroforestri Suren (Toona sureni Merr.) dan Kopi Arabika (Coffea arabica L.) (Departemen Manajemen Hutan, Fakultas Kehutanan, Universitas Sumatera Utara, Medan, 2016)

19. Widya, S, Model Pendapatan Masyarakat Terhadap Tanaman Suren (Toona sureni Merr.) dan Tanaman Kakao (Theobroma cacao L.) di Desa Mekar Sari Raya, Kecamatan Panei, Kabupaten Simalungun (Departemen Manajemen Hutan, Fakultas Kehutanan, Universitas Sumatera Utara. Medan, 2015)

20. Latifah, S., Muhdi., Purwoko, A., Etika, T, Journal BIODIVERSITAS, 19, 670-675 (2018) 